\title{
TANTANGAN BERKARIER SUMBER DAYA MANUSIA LOKAL DI INDUSTRI PERHOTELAN SANUR
}

\section{CAREER CHALLENGES IN LOCAL HUMAN RESOURCES IN SANUR HOSPITALITY INDUSTRY}

\author{
Retno Juwita Sari \\ Sekolah Tinggi Pariwisata Bali Internasional \\ ithajuwita13@gmail.com
}

\begin{abstract}
From the analysis, it is found that there were still many challenges experienced by local communities in exploiting job opportunities, such as the incompatibility between labor qualifications required by the tourism industry and the capacity of local communities. The lack of capacity of human resources resulted from the low quality of education, the lack of knowledge and skills in the tourism industry, especially the hospitality, and the attitude and behavior or work ethic of the local community itself. The success or failure of cooperative relationship between the company and its human resources is inseparable from the role of desa adat. The role of desa adat here is to provide job-related information required by the company to assist the prospective workforce to obtain a job. The tourism sector is expected to build motivation and increase work productivity for the community in order to encourage the growth of the economic sector.
\end{abstract}

Keywords: Local Human Resources, Productivity, Training and Development

\begin{abstract}
ABSTRAK
Dari analisis, ditemukan bahwa masih ada banyak tantangan yang dialami oleh masyarakat lokal dalam mengeksploitasi peluang kerja, seperti ketidakcocokan antara kualifikasi tenaga kerja yang dibutuhkan oleh industri pariwisata dan kapasitas masyarakat lokal. Kurangnya kapasitas sumber daya manusia disebabkan oleh rendahnya kualitas pendidikan, kurangnya pengetahuan dan keterampilan dalam industri pariwisata, terutama keramahan, dan sikap dan perilaku atau etos kerja masyarakat setempat itu sendiri. Keberhasilan atau kegagalan hubungan kerja sama antara perusahaan dan sumber daya manusianya tidak terlepas dari peran desa adat. Peran desa adat di sini adalah untuk menyediakan informasi terkait pekerjaan yang dibutuhkan oleh perusahaan untuk membantu calon tenaga kerja untuk mendapatkan pekerjaan. Sektor pariwisata diharapkan dapat membangun motivasi dan meningkatkan produktivitas kerja bagi masyarakat dalam rangka mendorong pertumbuhan sektor ekonomi.
\end{abstract}

Kata kunci: Sumber Daya Manusia Lokal, Produktivitas, Pelatihan dan Pengembangan

\section{PENDAHULUAN}

Industri pariwisata perhotelan merupakan salah satu industri yang mampu menyerap tenaga kerja dengan jumlah yang banyak. Menurut perbandingan jauh 
lebih banyak dibutuhkan tenaga kerja untuk hotel dan restoran daripada usahausaha lain. Masyarakat setempat memiliki peluang yang sangat besar dalam memanfaatkan kesempatan tersebut, terutama dalam mendukung kebutuhan tenaga kerja pada industri pariwisata perhotelan di Sanur. Namun, sejauh ini masih banyak kendala yang dialami oleh masyarakat lokal dalam memanfaatkan peluang tersebut, seperti adanya ketidaksesuaian antara kualifikasi tenaga kerja yang dibutuhkan oleh industri pariwisata perhotelan dengan kapasitas yang dimiliki oleh masyarakat lokal. Rendahnya kapasitas sumber daya manusia dapat dipengaruhi oleh rendahnya kualitas pendidikan, minimnya pengetahuan dan keterampilan di bidang industri pariwisata khususnya perhotelan, serta sikap dan perilaku atau etos kerja yang dimiliki oleh masyarakat lokal itu sendiri.

Kapasitas masyarakat dalam memanfaatkan peluang kerja dari sektor pariwisata dapat disebabkan oleh berbagai hal, peran pemerintah daerah pun merupakan salah satu bagian yang terpenting dalam meningkatkan perekonomian daerah setempat. Pada kenyataannya, permasalahan umum yang terjadi di lapangan adalah tingginya standar kualifikasi tenaga kerja yang dibutuhkan oleh industri pariwisata khususnya di industri pariwisata yang ada di Sanur. Tingginya standar kualifikasi yang dibutuhkan karena industri pariwisata merupakan industri yang bergerak dibidang jasa, sehingga kepuasan bagi konsumen tergantung dari pelayanan yang diberikan oleh sumber daya manusia yang dimilikinya. Industri jasa seringkali dikarakteristikkan sebagai transaksi dari suatu hal yang tidak berwujud yang dilakukan antara penyedia jasa dan konsumen (Gronroos, 1990).

Begitupula dengan karyawan hotel yang ada di kawasan pariwisata Sanur yang selama ini memegang peranan sangat penting dalam meningkatkan kualitas pelayanan kepada pelanggan hotel, baik pelanggan domestik maupun mancanegara. Dengan meningkatnya persaingan antar hotel yang ada di Sanur untuk mendapatkan pelanggan, menuntut terjadinya peningkatan kualitas pelayanan yang diberikan oleh karyawan.

Adapun alasan mengapa penulis memilih topik ini karena pada artikel sebelumnya belum ada yang membahas mengenai tantangan sumber daya manusia lokal dalam berkarier pada industri perhotelan, maka dengan adanya artikel ini diharapkan para pembaca dapat mengetahui kendala dan tantangan sumber daya manusia lokal untuk berkarier pada industri perhotelan, serta mengetahui pula strategi yang mereka miliki dalam menghadapi permasalahan-permasalahan yang dihadapi dalam berkarier.

\section{METODE PENELITIAN}

Teori yang digunakan dalam artikel ini adalah Teori Perencanaan Sumber Daya Manusia, Teori Produktivitas Kerja dan Teori Pelatihan dan Pengembangan Sumber Daya Manusia. Milkovich dan Nystrom, (Yoder, 1981: 173) mendefinisikan bahwa:

"Manpower planning is the process (including forecasting, development, implementing, and controlling) by which of firm ensures that is has the right number of people and the right place, at the economically most useful"

"Perencanaan tenaga kerja adalah proses peramalan, pengembangan, pengimplementasan, dan pengontrolan yang menjamin perusahaan mempunyai 
kesesuaian jumlah pegawai, penempatan pegawai secara benar, waktu yang tepat, yang sangat bermanaat secara ekonomis".

Produktivitas kerja dapat dilihat dalam berbagai output seperti tingkat penjualan, jumlah produk, jumlah konsumen yang dilayani, atau panggilan yang diangkat setiap harinya. Employee performance merupakan faktor yang cukup mempengaruhi efektivitas dan efisiensi kerja. Oleh karena itu, input yang paling umum dalam penghitungan produktivitas kerja adalah jumlah jam tenaga kerja karyawan (Russel \& Taylor, 2011).

Sikula (2011) mengemukakan bahwa pelatihan (training) adalah suatu proses pendidikan jangka pendek yang mempergunakan prosedur sistematis dan terorganisasi, pegawai non majerial, mempelajari pengetahuan dan ketrampilan teknis dalam tujuan yang terbatas. Pengembangan merupakan suatu proses pendidikan jangka panjang yang mempergunakan prosedur sistematis dan terorganisasi yang pegawai manajerialnya mempelajari pengetahuan konseptual dan teoritis untuk mencapai tujuan yang umum.

Dengan demikian, istilah pelatihan ditujukan pada pegawai pelaksana untuk meningkatkan pengetahuan dan ketrampilan teknis, sedangkan pengembangan ditujukan pada pegawai tingkat manajerial untuk meningkatkan kemampuan konseptual, kemampuan dalam pengambilan keputusan, dan memperluas hubungan manusia.

\section{HASIL DAN PEMBAHASAN \\ A. Kendala Internal dan Eksternal SDM Lokal dalam Berkarier di Perhotelan Sanur}

Pariwisata diharapkan sebagai sektor andalan dan unggulan yang mampu menjadi salah satu penghasil devisa negara, mendorong pertumbuhan ekonomi, meningkatkan pendapatan daerah, pemberdayaan perekonomian masyarakat serta memperluas kesempatan kerja. Berikut adalah beberapa kendala sumber daya manusia lokal yang ada di kawasan pariwisata Sanur:

\section{Kendala Internal}

a. Pendidikan

Masalah yang berkaitan dengan pengembangan sumber daya manusia yang dihadapi oleh negara kita yaitu Indonesia adalah mengembangkan kuantitas dan kualitas sumber daya manusia dalam menghadapi dinamika perkembangan dunia yang cepat. Ini berarti tingkat pendidikan sebagai salah satu cara untuk meningkatkan kualitas sumber daya manusia. Manusia harus terus dikejar, serta menciptakan kesempatan kerja yang mencakup pemanfaatan sumber daya manusia secara maksimal yang memiliki tingkat produktivitas tinggi. Pendidikan merupakan upaya penting dalam peningkatan mutu sumber daya manusia yang pada akhirnya akan berperan menentukan di dalam pemanfaatan Sumber Daya Alam demi peningkatan mutu kehidupan berdasarkan pemikiran-pemikiran yang wawasan masa depan.

Tabel 1. Penduduk Kawasan Sanur Menurut Tingkat Pendidikan

\begin{tabular}{|l|l|l|l|l|}
\hline $\begin{array}{l}\text { Tingkat } \\
\text { Pendidikan }\end{array}$ & $\begin{array}{l}\text { Kelurahan } \\
\text { Sanur }\end{array}$ & $\begin{array}{l}\text { Sanur } \\
\text { Kaja }\end{array}$ & Total & $\%$ \\
\hline Belum Sekolah & 692 & 640 & 1955 & 8.02 \\
\hline
\end{tabular}




\begin{tabular}{|l|l|l|l|c|}
\hline Belum Tamat SD & 2831 & 1144 & 6173 & 25,33 \\
\hline SD & 1542 & 1736 & 4767 & 19,56 \\
\hline SMP & 1499 & 1708 & 4660 & 19,12 \\
\hline SMA & 1629 & 2244 & 5447 & 22,35 \\
\hline DI-III & 117 & 166 & 395 & 1,62 \\
\hline D4-SARJANA & 282 & 419 & 973 & 3,99 \\
\hline Jumlah & 8592 & 8057 & 2437 & 100,00 \\
\hline
\end{tabular}

Walaupun kawasan Sanur berada di daerah tujuan wisata, tetapi penduduk Sanur sebagian besar belum tamat SD (25.33\%), Sekolah Dasar (19.56 \%) dan SMP (19.12\%), dan hampir seperempatnya berpendidikan SMA (22.35\%). Hanya sebagian kecil penduduk kawasan Sanur yang sudah mengenyam bangku pendidikan tinggi, yaitu program Diploma I-III (1.62\%) dan Sarjana (3.99\%).

Pada dasarnya, pendidikan harus dilihat sebagai tujuan dan sekaligus juga sebagai proses pendidikan dilakukan untuk mencapai sesuatu, akan tetapi juga menunjuk kepada proses yang terjadi sepanjang hayat. Sedangkan dari segi pelaksanaannya, keterwujudan tujuannya sepenuhnya tergantung kepada prosesnya.

b. Bahasa

Sumber daya manusia yang bekerja pada industri pariwisata, khususnya dalam perhotelan semestinya dibekali dengan skill bahasa yang mumpuni, bahasa yang dimaksud disini adalah penggunaan bahasa asing. Industri pariwisata menuntut sumber daya manusia yang bekerja didalamnya dapat berkomunikasi secara langsung dengan para customer yang berasal dari luar negeri misalnya, karena akan sangat memudahkan keduanya untuk berinteraksi. Namun yang terjadi dilapangan adalah sumber daya manusia yang mungkin pendidikannya kurang atau kurang mengasah penggunaan bahasa inggrisnya, sangat kesulitan akan perbedaan bahasa tersebut.

c. Kemampuan Teknologi

Sekarang ini muncul juga kesadaran bahwa pembangunan tidak hanya bisa tergantung pada sumber daya alam. Teknologi sebagai sumber daya pembangunan yang lain memang menjadi penting pula belakangan ini. Namun perkembangan dan pemanfaatan teknologi itu sendiri sangat tergantung pada manusia. Sumber daya manusia yang memiliki kendala dalam penggunaan teknologi biasanya mereka yang tidak bekerja dalam office, artinya mereka yang mengandalkan tenaganya untuk menunjang pekerjaanya.

\section{Kendala Eksternal}

a. Lingkungan

Organisasi dikelilingi oleh suatu lingkungan eksternal yang terdiri dari berbagai variable. Keputusan-keputusan personalia yang menyangkut penarikan, seleksi, latihan, penempatan, transfer, promosi, penilaian prestasi kerja, disiplin, kompensasi dan sebagainya, harus diambil dengan memperhatikan berbagai kekuatan lingkungan tersebut. Sebaliknya, organisasi hanya mempunyai sedikit pengaruh. Berbagai tantangan lingkungan eksternal yang dihadapi sumber daya manusia lokal Sanur sangatlah berbeda-beda, yakni 
mencakup kondisi geografis, kondisi sosial budaya, tantangan ekonomi, tantangan demografis, dan pasar tenaga kerja.

Pada kondisi geografis, organisasi yang berlokasi di lingkungan yang aman, nyaman, dan bersih dengan berbagai fasilitas akan lebih mudah menarik para pelamar dibandingkan dengan organisasi yang berlokasi di daerah yang mempunyai tingkat kejahatan tinggi, terpencil atau pelosok. Berbagai keputusan yang menyangkut penarikan, transfer dan kompensasi hampir pasti berbeda di kedua lingkungan tersebut. Bahkan dalam organisasi yang sama, kebijaksanaan kompensasi bisa berbeda untuk pekerjaan yang sama di daerahdaerah dengan biaya hidup tinggi di satu pihak dan di daerah-daerah dengan biaya hidup rendah di lain pihak.

Kondisi sosial budaya merupakan pertimbangan penting bagi pengambilan keputusan personalia. Kondisi ini berkenaan dengan kepercayaan, nilai-nilai, sikap, pandangan dan pola atau gaya kehidupan yang berkembang dan terbentuk dari dinamika kebudayaan, geografis, religious, pendidikan dan faktor-faktor etnis lainnya. Peningkatan partisipasi wanita dalam pasar tenaga kerja adalah contoh pertama perubahan sosial yang mempunyai berbagai implikasi demografis. Selama peneliti melakukan penelitian di beberapa hotel yang ada di Kelurahan Sanur, memang jumlah tenaga kerja perempuan lebih banyak ketimbang jumlah tenaga kerja laki-laki.

Sejalan dengan perbaikan kondisi perekonomian, permintaan akan karyawan baru dan program-program latihan terus tumbuh dan berkembang. Perkembangan-perkembangan ini selanjutnya memberikan tekanan pada peningkatan upah, penawaran yang lebih baik, dan perbaikan kondisi kerja. Hal ini di dukung dengan apa yang peneliti dapatkan di lapangan bahwa, sebagian besar dari mereka yang sudah berkerja bertahun-tahun meminta kenaikan gaji pada tiap tahunnya.

b. Organisasional

Di samping faktor internal sumber daya manusia dan faktor lingkungan eksternal, juga terdapat tantangan-tantangan organisasional dari dalam organisasi. Berbagai tantangan internal timbul karena perusahaan mengejar sasaran-sasaran ganda. Sasaran-sasaran tersebut memerlukan keseimbangan antara tujuan finansial, pemasaran, produksi, personalia, dan lain-lain. Faktor organisasional ini meliputi faktor etika, faktor kesamaan kesempatan, perencanaan SDM, standard kualifikasi tenaga kerja, dan kondisi penawaran tenaga kerja,

Dalam proses seleksi, masalah etika seringkali menjadi tantangan yang berat. Keputusan seleksi seringkali dipengaruhi oleh etika pemegang keputusan. Bila pertimbangan penerimaan lebih condong karena hubungan keluarga, teman, pemberian komisi/suap dari pada pertimbangan keahlian/profesional, maka kemungkinan besar karyawan baru yang dipilih jauh dari harapan organisasi.

Budaya suatu daerah dalam memperlakukan masyarakatnya juga merupakan tantangan dalam proses seleksi. Diskriminasi masih sering ditemukan dalam merekrut/menseleksi pegawai yang disebabkan oleh warna kulit, ras, agama, umur, jenis kelamin, dan sebagainya. Sebagai contoh kebijaksanaan organisasi (walau tidak tertulis) yang lebih menyukai pegawai pria atau wanita. Kenyataan ini menghambat proses seleksi secara wajar. 


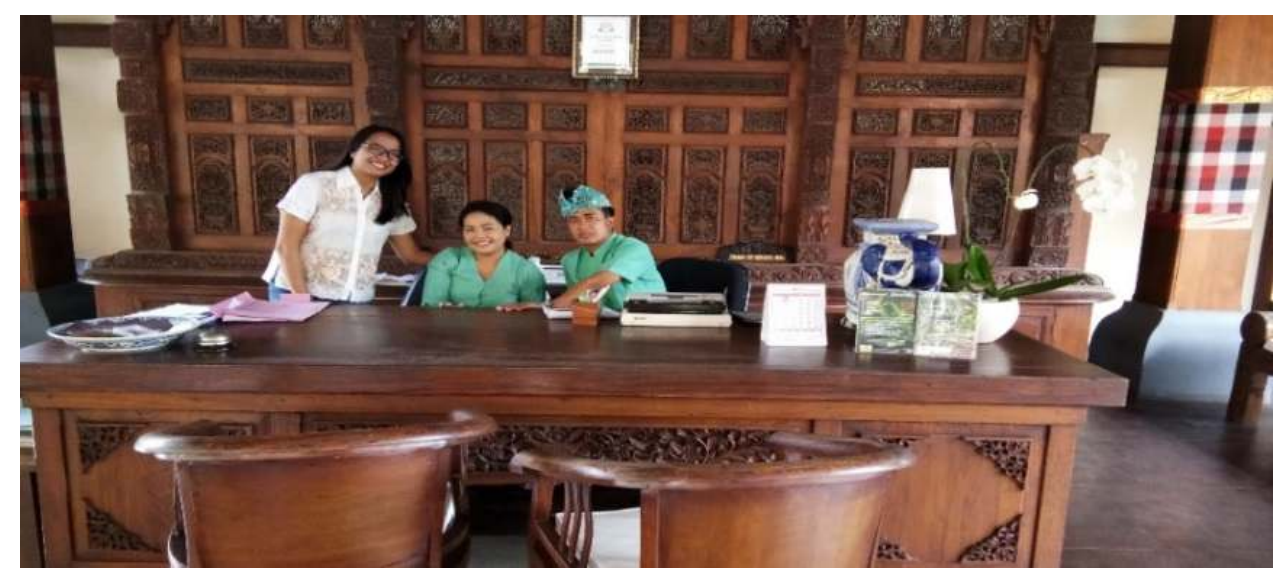

Gambar 1. Foto bersama karyawan hotel

Foto di atas adalah foto peneliti bersama dua karyawan front office. Meskipun keduanya berada di dalam satu divisi yang sama, namun keduanya memiliki kendala yang berbeda. Ibu Suasti misalnya, wanita yang sudah 16 tahun ini bekerja di industri perhotelan itu memiliki permasalahan dalam hal jadwal kerja.

Kepuasan wisatawan yang menikmati pelayanan hotel di Sanur sangatlah tergantung dari kinerja para karyawan di hotel tersebut, dan tentunya dapat mempengaruhi wisatawan untuk datang kembali dan tinggal dalam waktu yang lebih lama. Dengan demikian kepuasan wisatawan sangat tergantung terhadap kualitas pelayanan yang diberikan oleh penyedia sarana akomodasi.

Kualitas pelayanan yang baik juga sangat tergantung pada keberadaan kompetensi sumber daya manusia pada hotel tersebut. Pengelolaan kompetensi karyawan merupakan pengembangan seluruh potensi yang dimiliki karyawan dan membangun lingkungan kerja yang kondusif untuk menciptakan kinerja yang baik, memelihara peningkatan kontribusi dan kepuasan semua karyawan. Pemberdayaan SDM yang dilakukan secara terus menerus juga akan berdampak terhadap kualitas dan kepuasan konsumen.

Berdasarkan hasil penelitian yang ada di lapangan bahwa semakin besar jumlah pelamar yang memenuhi syarat (qualified), maka akan semakin mudah bagi organisasi untuk memperoleh karyawan yang berkualitas dan sebaliknya. Pada saat rekrutmen bisa terjadi jumlah calon yang terjaring lebih kecil dari yang diharapkan. Kondisi tersebut dimungkinkan karena imbalan/upah yang ditawarkan rendah, pekerjaan menuntut spesialisasi yang tinggi, persyaratan yang harus dipenuhi berat, dan mutu pelamar rendah.

\section{B. Strategi SDM Lokal dalam Mengatasi Kendala Internal dan Eksternal}

Manusia merupakan satu-satunya sumber daya yang dapat membuat sumber daya organinasi lainnya bekerja dan berdampak langsung terhadap kesejahteraan perusahaan. Berikut adalah strategi yang dapat diterapkan sumber daya manusia lokal untuk berkarier dalam industri perhotelan di kawasan pariwisata Sanur:

a. Meningkatkan Motivasi Kerja

Motivasi adalah hasrat yang timbul dalam diri seorang individu yang dapat disebabkan stimulasi, baik dari dalam diri maupun dari luar, sehingga 
orang tersebut memiliki semangat untuk melakukan hal-hal yang dapat menunjang bagi tujuan dirinya juga organisasi tanpa merasa tertekan atau merasa bahwa itu semua merupakan sebuah kewajiban semata. Sebab apa yang dikerjakan dengan kesungguhan hati dan keinginan yang murni akan berbeda hasilnya dengan hasil yang dikerjakan dengan penuh tekanan.

\section{b. Meningkatkan Produktivitas Kerja}

Penurunan produktivitas kerja masih sering terjadi. Permasalahan tentang produktivitas kerja ini merupakan permasalahan umum yang terjadi pada setiap perusahaan. Kadang produktivitas kerja seorang karyawan cenderung menurun dan pengaruhnya adalah merosotnya suatu perusahaan. Bila tidak diatasi dengan baik maka perusahaan tersebut akan cenderung mengalami penurunan yang signifikan. Pada penelitian ini yang dimaksud mengenai produktivitas kerja adalah kinerja karyawan atau performance yang merupakan hasil atau keluaran dari suatu proses.

Karyawan yang merupakan bagian dari organisasi atau perusahaan perlu ditingkatkan produktivitasnya sebagai feed back dari perusahaan untuk tetap menjaga dan mengikat daripada karyawan agar tetap bergabung dalam perusahaan tersebut. Kepuasan kerja bagi seorang karyawan akan berdampak positif bagi perusahaan, yang tentunya meningkatkan produktivitas bagi perusahaan tersebut. Individu sebagai karyawan memerlukan perhatian yang baik dalam kerjanya.

\section{c. Memberikan Pelatihan dan Pengembangan}

Pada latihan dan pengembangan inilah para sumber daya manusia yang memiliki permasalahan-permasalahan ataupun kendala-kendala yang mengganggu proses pekerjaan dapat mencari solusi atas permasalahannya. Antara lain mereka yang terkendala dalam penggunaan bahasa asing, khususnya bahasa Inggris harus lebih meningkatkan skill dalam berbahasa dengan cara kursus bahasa Inggris di luar jam kerja ataupun belajar dari teman yang memiliki tingkat kefasihan berbahasa asing yang lebih baik.

Latihan dan pengembangan mempunyai berbagai manfaat karier jangka panjang yang membantu karyawan untuk tanggungjawab lebih besar di waktu yang akan datang. Program-program latihan tidak hanya penting bagi individu, tetapi juga untuk perusahaan.

\section{d. Perencanaan Karier}

Suatu karier adalah semua pekerjaan yang dipunyai atau dipegang selama kehidupan kerja seseorang. Perencanaan karier diperlukan bagi para karyawan untuk selalu siap menggunakan kesempatan karier yang ada. Orang-orang sukses biasanya mengembangkan berbagai rencana karier dan kemudian berupaya untuk mencapai rencana-rencana mereka. Karier harus dikelola melalui suatu perencanaan yang cermat. Bila tidak, karyawan akan sering tidak siap memanfaatkan berbagai kesempatan karier.

Banyak orang gagal mengelola karier mereka, karena mereka tidak memperhatikan konsep dasar perencanaan. Mereka tidak menyadari bawa sasaran-sasaran karier dapat memacu karier mereka dan menghasilkan kesuksesan yang lebih besar. Pemahaman akan konsep-konsep tersebut 
tidak menajmin kegiatan, tetapi bila hal itu mengarahkan pada penetapan sasaran karier, peencanaan karier lebih cenderung terlaksana. Proses perencanaan karier ini memungkinkan para karyawan untuk mengidentifikasi sasaran-sasaran karier dan jalur-jalur menuju sasaran tersebut. Kemudian melalui kegiatan-kegiatan atau pengembangan para karyawan mencari cara untuk meningkatkan kualitas dirinya dan mengembangkan sasaran karier mereka.

\section{Peran Desa Adat dalam Mengakomodir Masyarakat Lokal Sanur untuk berkarier di Perhotelan}

Berdasarkan adanya faktor koordinasi dan faktor kemitraan, bahwasannya peran desa adat yang ada di Kelurahan Sanur ini sudah sebisa mungkin untuk membantu ataupun untuk mengakomodir sumber daya manusia untuk dapat bekerja maupun berkarier pada industri perhotelan. Peran mereka mulai dari memberikan informasi-informasi terkait pekerjaan yang dibutuhkan, hingga membantu calon pekerja agar diterima pada perusahaan, khususnya perhotelan. Sistem yang dianut sampai saat ini adalah sistem kerja sama antara investor dan banjar, yang berarti bahwa sumber daya manusia yang ingin bekerja pada hotel tertentu misalnya, setidaknya memiliki network di dalam hotel tersebut.

Di banjar Semawang, menerapkan perjanjian yang mana paling tidak memprioritaskan penerimaan dan penempatan tenaga kerja lokal sesuai dengan kemampuan yang dibutuhkan oprasional sebanyak 40\%. Ini berarti bahwa sudah ada MOU yang dibuat antar kedua belah pihak untuk membantu masyarakat lokal untuk dapat bekerja pada industri perhotelan, namun dilihat juga kompetensi masing-masing individu. Walaupun sudah ada kesepakatan antar kedua belah pihak tentang penerimaan tenaga kerja sebanyak $40 \%$, namun yang terjadi di lapangan adalah kurang dari angka tersebut.

\section{KESIMPULAN}

Dari hasil analisis dan pembahasan yang telah dilakuan dalam penelitian ini, maka dapat diperoleh simpulan sebagai berikut:

Pertama, terdapat 2 faktor yang menjadi kendala dalam sumber daya manusia lokal untuk berkarier, yakni faktor internal dan eksternal. Faktor internal sumber daya manusia lokal meliputi pendidikan, bahasa dan ketrampilan teknologi. Sedangkan faktor eksternal meliputi lingkungan dan organisasional. Faktor lingkungan meliputi kondisi geografis, kondisi sosial budaya, tantangan ekonomi, tantangan demografis, pasar tenaga kerja. Sedangkan faktor organisasioal meliputi faktor etika, faktor kesamaan kesempatan, perencanaan SDM, standar kualifikasi tenaga kerja yang dibutuhkan dan kondisi penawaran tenaga kerja.

Kedua, strategi yang perlu dilakukan oleh sumber daya manusia lokal untuk mengatasi kendala dalam berkarier adalah penguasaan informasi dan kemampuan memilih informasi tersebut. Disamping itu tentu saja meningkatkan pengetahuan dan keterampilan yang relevan dengan kebutuhan zaman yang diperoleh dengan salah satu cara, yakni meningkatkan tingkat pendidikan. Secara garis besar, masalah pokok yang berkaitan dengan pengembangan sumber daya manusia yang dihadapi adalah mengembangkan kuantitas dan kualitas sumber daya manusia 
dalam menghadapi dinamika perkembangan dunia yang cepat. Ini berarti tingkat pendidikan sebagai salah satu cara untuk meningkatkan kualitas sumber daya manusia, serta menciptakan kesempatan kerja yang mencakup pemanfaatan sumber daya manusia secara maksimal yang memiliki tingkat produktivitas tinggi.

Dari hasil analisis terhadap peran desa adat dalam mengakomodir masyarakat lokal agar dapat berkarier pada industri perhotelan di Sanur adalah melalukan koordinasi, kerjasama antar hotel dibawah naungan desa adat dan memberikan rekomendasi kepada hotel yang bersangkutan. Sukses atau tidaknya hubungan kerjasama antara perusahaan dan sumber daya manusianya ialah tidak lepas dari peran desa adat. Peran desa adat di sini adalah untuk memberikan informasi-informasi terkait pekerjaan yang dibutuhkan oleh perusahaan hingga membantu calon tenaga kerja agar dapat diterima bekerja. Adanya peran desa adat terhadap pihak perhotelan melalui koordinasi dan hubungan kemitraan adalah upaya dalam hal menumbuhkembangkan kualitas sumber daya manusia dengan mengembangkan sistem/struktur organisasi tanpa batas. Dengan berorganisasi, masyarakat dapat menempa potensi diri mereka masing-masing dalam organisasi, melalui peningkatan kreativitas dan inovasi.

Saran yang dapat direkomendasikan kepada pihak-pihak terkait adalah sebagai berikut. Pertama, Masyarakat sebagai sumber daya utama dalam perkembangan pariwisata, khususnya di Sanur harus mampu menyadari kebutuhan akan kompetensi agar mampu bersaing dalam industri pariwisata yang terus berkembang. Masyarakat diharapkan dapat berperan dalam tingkat manajerial atau pengelolaan dan pengambilan keputusan yang berkaitan dengan pariwisata sehingga keputusan atau kebijakan dalam pariwisata tidak ada yang bersifat merugikan masyarakat.

Kedua, bagi pemerintah seharusnya menyediakan suatu lembaga yang mungkin masuk ke dalam golongan lembaga non formal untuk menjadi wadah bagi masyarakat yang memiliki keterbatasan dari segi ekonomi ataupun dari segi skills. Lembaga pendidikan bertujuan untuk menghasilkan sumber daya manusia yang berkualitas untuk memenuhi kebutuhan pasar kerja.

Ketiga, bagi perusahaan juga harus mementingkan program latihan dan pengembangan sumber daya manusia. Latihan dan pengembangan mempunyai berbagai manfaat karier jangka panjang yang membantu karyawan untuk tanggungjawab lebih besar di waktu yang akan datang. Program-program latihan tidak hanya penting bagi individu, tetapi juga untuk perusahaan. Karyawan yang merupakan bagian dari organisasi atau perusahaan perlu ditingkatkan produktivitasnya sebagai feedback dari perusahaan untuk tetap menjaga dan mengikat daripada karyawan agar tetap bergabung dalam perusahaan tersebut.

Keempat, penelitian lebih lanjut perlu dilakukan dengan memperhatikan aspek yang lain seperti mengimplementasikan sumber daya manusia dalam pendidikan dan pemberdayaan sumber daya manusia lokal itu sendiri. Selain itu penelitian terkait organisasi ataupun lembaga yang berpartisipasi dalam usaha pelatihan dan pengembangan sumber daya manusia lokal juga perlu digali lebih dalam, karena hal itu juga dapat mempengaruhi motivasi dan produktivitas sumber daya manusia yang ingin berkarier dalam industri perhotelan. 


\section{UCAPAN TERIMA KASIH}

Penulis menyampaikan ucapan terima kasih kepada Prof. Dr. Made Budiarsa, M.A dan Dr. Dewa Putu Oka Prasiasa, A. Par., MM selaku pembimbing I dan II yang telah bersedia meluangkan waktu, tenaga, dan pikiran untuk melakukan bimbingan dengan sabar dalam penyelesaian tesis ini. Kepada Dr. Drs I Nyoman Sunarta selaku Dekan Fakultas Pariwisata Universitas Udayana dan sebagai dosen penguji terima kasih atas kesempatan dan fasilitas yang diberikan kepada penulis untuk mengikuti dan menyelesaikan Program Magister di Universitas Udayana. Tidak lupa penulis ucapkan terima kasih kepada Prof. Dr. I Nyoman Darma Putra, M.Litt selaku dosen dan penguji yang memberikan bimbingan dengan sabar, menyajikan perkuliahan bermanfaat dan berkesan bagi penulis hingga dapat menyelesaikan Program Magister di Universitas Udayana. Dr. I Putu Gde Sukaatmadja, S.E., M.P selaku dosen penguji yang telah memberikan banyak saran dan koreksi untuk perbaikan dalam penyelesaian tesis.

\section{DAFTAR PUSTAKA}

Andrew, Sikula. 2011. Pelatihan dan Pengembangan Tenaga Kerja. Jakarta: Pustaka Binaman.

Gronroos, C. 1990. Service Management and Marketing: Managing the Moment of Truth in Service Competition. Massachussets: Lexington.

Hanantijo. 2006. Strategi Sumber Daya Manusia dalam Menghadapi Persaingan Global. Universitas Surakarta.

Hartatik, Indah Puji. 2014. Buku Praktis Mengembangkan MSDM. Yogyakarta: Laksana.

Hetifah. 2011. Memahami Aspek-Aspek Pengelolaan Sumber Daya Manusia dalam Organisasi. Jakarta: PT. Grasindo.

Indarto, Stef. 2000. Sumber Daya Manusia Bidang Perhotelan. Yogyakarta.

Kadarisman, M. 2012. Manajemen Pengembangan Sumber Daya Manusia. Jakarta: PT. Rajagrafindo Persada.

Nawawi, Hadari, 2011, Manajemen Sumber DayaManusia, Yogyakarta: Penerbit Gadjah Mada University Press.

Rahman, Nur Abdul. 2003. Kapasistas Sumber Daya Manusia Lokal pada Industri Pariwisata Perhotelan di Kelurahan Kuta. Jurnal Perencanaan Wilayah dan Kota. Universitas ITB.

Robbin, Stephen P. \& A. Judge, Timothy. 2011. Organizational Behavior. Fourteenth Edition. Person education. New Jersey.

Russel, R. S. dan Taylor, B.W. 2011. Operations Management: Along the Supply Chain, $7^{\text {th }}$ ed. New Jersey: Wiley.

Sedarmayanti. 2009. Sumber Daya Manusia Dan Produktivitas Kerja. Bandung: Mandar Maju.

Schulter, R.S. \& Huber, L.V. 1993. Personnel \& Human Resource Management. Minn-West, St. Paul.

Yoder, Dale. 1981. Personnel Management and Industrial Relation. New Delhi: Prentice-Hall of India Private Limited. 